\title{
Urban Agencies: Reframing Anatolian and Caucasian Cities (13th-14th Centuries) Preface
}

\section{Matthew Kinloch and Bruno De Nicola}

This thematic section in Medieval Worlds came about by chance. We (Matthew Kinloch and Bruno De Nicola) arrived in Vienna within a few months of each other to carry out research, in the Division of Byzantine Research at the Institute for Medieval Research and the Institute of Iranian Studies, respectively. Finding ourselves working in the same building of the Austrian Academy of Sciences, we bumped into each other and conversations over coffee turned into discussions over lunch, which led (as most things do in academia) to the organisation of a workshop.

Since our individual research, on Byzantine and Islamic history and literature, respectively, concentrated on the same period and on overlapping geographical spheres our conversations started to revolve around the various difficulties in framing our research outside of restrictive narratives dominated by specific state projects. Although our research specialisation and the disciplinary fields in which we operate present different problems and potentials, the broader similarities proved striking.

Since Matthew was investigating the agency of village and urban communities in Byzantine histories and monastic documents, as part of the Wittgenstein-Preis project Moving Byzantium: Mobility, Microstructures, and Personal Agency and Bruno was just finishing his monograph on the literary history of the Chobanid dynasty of Kastamonu (Routledge, 2022), the potential of using urban centres as a platform for asking questions about our shared interests presented itself more or less of its own accord.

Keen to organise the workshop outside of state-centric narrative structures, such as Byzantine or Seljuq, we sought to define at least the basic parameters of the meeting through geographical terms, eventually settling on the ugly compromise of medieval Anatolian and Caucasian cities. As is now apparent, even this framing (which did not fill either of us with much enthusiasm) proved too limited for the contributions we received, with some papers straying across the Aegean into southeastern Europe. All this terminological wrangling simply goes to illustrate the difficulties of even framing the phenomena we were interested in without reference to states.

Within the workshop and subsequently in the articles published in this issue, our collaborators approached various aspects of urban agency in different parts of medieval Anatolia, Caucasia, and the Aegean from a variety of theoretical and methodological perspectives. The first article by Matthew Kinloch, seeks to set out a theoretical and methodological framework for the articles that follow, as well as to offer a concrete example of that framework's potential. His paper engages with state-centric narratives and the manner in which they continue to shape much scholarship on the period. Despite scholars being well aware of the problems and seeking to cut across the often arbitrary divisions imposed by states, narratives focused on states, such as the decline of Byzantium and the rise of the 
Ottomans, are simply such useful constructs for presenting action in this period that they have proved difficult to displace. Kinloch seeks to identify some of the potential that a focus on urban centres and the agencies of the people who lived in them can have for the study of the period. To do so, he offers the example of conflict around the city of Attaleia/Antalya/ Satalia in 1206/1207 and the manner in which analyses of this period have been integrated into and made meaningful within state-centric reconstructions of the history of the early thirteenth century.

Following this broad framing, Andrew Peacock's contribution focuses on an analysis of agency in medieval Islamic Anatolian cities. He questions the tendency in Turkish historiography that sees the institution of futuwwa (trade-based confraternities) as evidence of urban autonomy. Instead, he suggests that there were urban elites (a'yān) who are more representative of urban agency in Anatolia as they mediated between the futuwwa and the rulers. This view on Anatolia Islamic cities is complemented by Teresa Shawcross's analysis of Byzantine cities in the empire's western provinces (particularly Thrace and Macedonia). In her article, she explores the negotiation of power between the Byzantine imperial centre and its increasingly assertive cities. This study explores the changing face of urban economies and politics in a period in which the gulf between the rhetoric and reality of imperial power shifted dramatically. As well as focusing on the western provinces of the Byzantine Empire, Shawcross looks yet further west for comparanda between forms of urban agency and power articulated on the contemporary Italian peninsula, thus providing an even wider transhistorical scope for this thematic section.

Urban centres in medieval Anatolia played an important role in facilitating trade and the circulation of goods. The strategic location of the peninsula between the Black Sea and the Mediterranean and its relationship to the so-called Silk Road, gave some Anatolian cities a relevant role in the administration of commerce. In this context, İklil Selçuk explores sources outlining codes of moral conduct to be used in markets in medieval Anatolian cities. Here again, the role of the akhis as members of futuwwa organisations acquire a central role in understanding commercial exchanges in urban settlements. By exploring different narrative sources, Selçuk argues that religious and moral teachings must be considered alongside state action in order to understand market regulation in medieval Islamic Anatolia. The relationship between the state and accumulation is also central to the argument of Nicholas Matheou, whose article examines the specific relationship between merchant capital and taxation in processes of urbanisation and deurbanisation in the city of Ani over the course of the long thirteenth century. This study offers a thorough investigation of the relationship between urban elites and subaltern counterpower, whilst situating this story in the wider dynamics of central Eurasian processes of state building and accumulation. In a study that shifts from the contemporary theorising of Ibn Khaldun to the built environment of Ani and back, Matheou demonstrates how to read subaltern counterpower in the accumulative practices of elite classes. His study of Ani thus not only demonstrates the potential of approaching medieval Caucasia through the dynamics of urban centres, but also what such studies have to contribute to the wider story of capitalist modernity itself. 
The arrival of the Mongols in Anatolia in the mid-thirteenth century conditioned the relationship between centres and peripheries across the peninsula, affecting urban agency in different ways according to the proximity or distance of the Mongol court in Iran. Oya Pancaroğlu's contribution, for example, focuses on the city of Ahlat, located on Lake Van, which was in close proximity to the Mongol centre of power in Tabriz. Relying on the survival of a series of tomb towers from the late thirteenth century, Pancaroğlu reconstructs urban agency in the city as these tombs belonged exclusively to Mongol amirs sent by the Ilkhanid rulers to control the city. Her study offers a very early account of the Islamisation of these Ilkhanid officials marked by the traces of Sufi sawiyyas in the outskirts of the city of Ahlat. At the other end of this geographical spectrum, in the far western parts of Islamic Anatolia in the thirteenth century, lies the city of Kastamonu, where Bruno De Nicola focusses his analysis on urban agency in the region as a borderland between Islam and Christianity. Using architectural and non-narrative historical sources, he reconstructs potential scenarios for the interaction between the Turkmen rulers that settled in the area from the late twelfth century and the inhabitants of Kastamonu during the thirteenth century. He argues that in a small city such as Kastamonu, urban agency can be observed in the relationship between Turkmen rulers and a Persianised intellectual and religious elite which materialised in the attempt to establish an administrative system for the city modelled on the theories of government developed during the period of the Great Seljuqs. The efforts and resources invested by these rulers and elites in controlling urban and fortified settlements in the borderlands with Byzantium during the thirteenth century were not limited to this period but remained in the collective memory of early Ottoman historians at the beginning of the sixteenth century. These Ottoman constructions of the past are the topic of Dimitri Korobeinikov's contribution, which closes this thematic section. He argues that Ottoman self-representations of their rule over Anatolia were so deeply grounded in the memory of a line of fortified urban defences against Byzantium during the thirteenth and fourteenth century, that it impacted on the imperial aspirations of the Ottoman rulers during the time of Sultan Sulaymān the Magnificent.

As well as the contributors we were fortunate to receive the enthusiastic intellectual, administrative, and financial support of Claudia Rapp and Florian Schwarz. ${ }^{1}$ In addition to the researchers who contributed written articles featured in this thematic section, we are grateful for the contributions of Aslı Akışık, Annika Asp, Emilio Bonfiglio, Suna Çağaptay, Rachel Goshgarian, Ekaterini Mitsiou, Wiktor Ostaz, Naomi Pitamber, Johannes Preiser-Kapeller, Ioanna Rapti, Scott Redford, and Sara Nur Ylldız at the workshop itself, without whose support the printed papers would have developed in less exciting ways. This project would not have been possible without the wider institutional and intellectual community at the Austrian Academy of Sciences. Foundational work in the historical geography of this period and space has been carried out in the Division of Byzantine Research within the framework of the Tabula Imperii Byzantini since 1966. ${ }^{2}$ We are also keen to express our gratitude to Bettina Hofleitner and Ingrid Hartl for their invaluable support during various stages of the project.

1 The workshop was financed by the Wittgenstein-Award project "Moving Byzantium: Mobility, Microstructures and Personal Agency « funded by the FWF Austrian Science Fund (Project Z 288-G25, PI: Prof. Claudia Rapp; rapp. univie.ac.at) and the Institute of Iranian Studies of the Austrian Academy of Sciences.

2 Most recently and relevantly, the period between the workshop and the publication of this issue of Medieval Worlds has seen the publication of TIB 13, Klaus Belke, Bithynien und Hellespont, Tabula Imperii Byzantini 13 (Vienna, 2020). 